\title{
Cattle preference for 4 warm-season grasses in La Pampa, Argentina
}

\author{
N Stritzler 1,2, C Rabotnikof 2, C Ferri 2, J Pagella 2, V Jouve 2

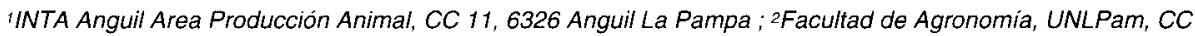 \\ 300, 6300 Santa Rosa, La Pampa, Argentina
}

Cattle preference for different forage species is one of the most important components of beef production under free-ranging conditions of semiarid and arid zones. In the present work, preference for 4 perennial warm-season grasses, and its relationship with nutritive value were studied.

Four adult Holstein-Friesian steers were used to evaluate the following species: Tetrachne dregeii (Td), Panicum virgatum $\mathrm{cv}$ Pathfinder (Pv), Panicum coloratum Selection 75 (Pc) and Eragrostis curvula cv Tanganyka (Ec). Ec was taken as a reference, since it has been widely tested in the region. The plants were distributed in field plots within a complete randomized design. Three groups $(\mathrm{B} 1, \mathrm{~B} 2$, and B3) of 20 plots each were used in the experiment. Each group included 5 replications per species. B1 was grazed in spring (S) and the regrowth in summer $(\mathrm{SmR})$ and winter (WR), B2 was grazed in summer (Sm) and the regrowth in winter (WRR) and B3 was grazed only in winter (W). Each animal was watched by one observer. Observations continued until the animals showed clear signs of no grazing preference. Grazing time lasted for 20 minutes (WR and WRR), $25 \mathrm{~min}(\mathrm{~S})$ and $60 \mathrm{~min}(\mathrm{Sm}, \mathrm{W}$ and $\mathrm{SmR}$ ). Visit sequence and grazing time was recorded for each species. Half of each plot was cut before grazing in order to determine dry matter yield, in vitro dry matter digestibility (IVDMD), crude protein (CP), neutral detergent fiber (NDF), acid detergent fiber (ADF) and lignin (L). Residual herbage was harvested and subjected to the same chemical analysis and dry matter intake (DMI) was estimated by difference.

Significant differences $(P<0.05)$ between species were found for all grazing dates (SmR, WR, Sm, WRR, and W) but $S$, when no clear preference for any grass was observed. Td was the most preferred species for W, WR and WRR. Grazing time of the regrowth was associated to $\%$ of $\mathrm{CP}$ by the following equation : $y=229.4-144.7 x+33.0 x^{2}$ $\left(R^{2}=0.61, S E=116.8\right)$

where: $y=$ grazing time of the regrowth

$$
\mathrm{x}=\% \mathrm{CP}
$$

No other relationship between time spent on grazing and quality parameters of forage could be detected.

Tetrachne dregeii is a highly preferred warmseason grass when it is consumed during winter. Nonetheless, Td did not show difference with the other species in spring.

\begin{tabular}{|c|c|c|c|c|c|c|c|}
\hline \multirow[b]{2}{*}{ Species } & \multirow[b]{2}{*}{$\mathrm{S}$} & \multirow{2}{*}{ 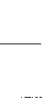 } & \multirow[b]{2}{*}{$\mathrm{Sm}$} & \multicolumn{2}{|c|}{ Grazing time (in seconds) } & \multirow[b]{2}{*}{ WRR } & \multirow[b]{2}{*}{ WR } \\
\hline & & & & W & SmR & & \\
\hline $\mathrm{Td}$ & $166^{a}$ & & $1143^{a}$ & 1893a & $786 \mathrm{ab}$ & 433a & $500^{a}$ \\
\hline Pv & $435^{a}$ & & 1038ab & $42^{b}$ & $1035^{a}$ & $77^{\mathrm{b}}$ & $28^{b}$ \\
\hline$P_{C}$ & $308^{a}$ & & $314 \mathrm{bc}$ & $119^{b}$ & $62^{c}$ & $203^{a b}$ & $108^{b}$ \\
\hline Ec & $299 a$ & & $236^{c}$ & $37 \mathrm{~b}$ & $170^{\mathrm{bc}}$ & $61^{\mathrm{b}}$ & $25^{b}$ \\
\hline - & $\ldots$ & - & - & -- & & & \\
\hline
\end{tabular}

